\title{
Virtual screening of RAGE inhibitors using molecular docking
}

\author{
Malini Devi Alaparthi, Gudipudi Gopinath, Srinivas Bandaru, Venu Sankeshi, Madhavi \\ Mangalarapu, Swetha Sudha Nagamalla, Kota Sudhakar, Anupalli Roja Rani, Someswar Rao \\ Sagurthi*
}

Department of Genetics \& Biotechnology, Osmania University, Hyderabad, Telangana, India; E-mail: drsomeswar@osmania.ac.in; ${ }^{*}$ Corresponding author

Received January 29, 2016; Revised April 8, 2016; Accepted April 9, 2016; Published June 15, 2016

\begin{abstract}
:
Advanced Glycation End products (AGEs) interaction with Receptor for AGEs (RAGE) activates downstream signaling and evokes inflammatory responses in vascular cells. Therefore, it is of interest to design a novel series of molecules with a library of 352 compounds based on natural Isoflavone and Argpyrimidine moities. The compounds screened against the optimized structure of RAGE (PDB code: 3CJJ) using MolDock aided with molecular docking algorithm. This exercise identified compound number 62 with appreciable ADME properties having no toxicity and pharmacophore features. Therefore, compound 62 identified as a RAGE inhibitor is proposed for further validation in the context of Diabetic Retinopathy (DR) and vascular complications.
\end{abstract}

Keywords: RAGE, molecular docking, ADMET prediction.

\section{Background:}

According to International Diabetes Federation, approximately 382 million people are suffering from diabetes worldwide, which is estimated to be $8.3 \%$ of the world's adult population in 2013. The prevalence rate may rise to 592 million people by 2035 [1]. In a pooled analysis performed by Yau et al. (2012) a total 93 million people are suffering from different types of DR [2]. Analyzing the above data it showed that $24.34 \%$ of diabetic patients are suffering with DR, which means one person out of four diabetic patients are suffering with DR. In addition to this, earlier studies predicts that people who become blind due to DR have limited life expectancy, this might be due to high AGEs which eventually add to diabetic secondary complications. The pathogenesis of DR is multi-factorial and is one of the leading causes of visual impairment. Chronic exposure of retina to high glucose levels leads to accumulation of AGEs, which plays an important role in the DR. Whenever AGEs interacts with RAGE downstream signaling activates and evokes the inflammatory response in vascular wall cells. Thus, targeting RAGE acts as a promising target for therapeutic intervention to prevent diabetic vascular complications. Various RAGE inhibitors like 2-amino pyrimidines, pyrazole-5-carboxamide derivatives and 6Phenoxy-2-phenylbenzoxazoles were synthesized and characterized to control the vascular complications in Alzhimers disease [3-4]. Considering this, based on the homology of RAGE receptors we rationally designed a significant number of small molecules as RAGE antagonist. These compounds have been designed by combining key structural moieties of Isoflavones and Argpyrimidines. Simultaneously, we carried out pharmacological analysis of these compounds by using different computational tools.

\section{Methodology:}

Compound dataset:

Earlier studies have shown that various RAGE inhibitors like 2aminopyrimidines and Pyrazole-5-carboxamides have been synthesized and characterized to control the vascular complications of Alzheimer's disease [3-4]. Flavonoids and isoflavonoids are manifested to be scavengers of methylglyoxal (MGO), a major precursor of AGEs by trapping MGO or glyoxal; in addition, RAGE specifically recognizes MGO derived AGEs [5-7]. Therefore, in view of above studies and homology of RAGE receptors we rationally designed 352 diverse compounds as shown in Figure 1 scaffold. By using variety of permutations and combinations at different substitutions on scaffold as RAGE antagonist, which were also anticipated to act 
as MGO scavengers. These compounds have been designed by fusing key structural moieties of Isoflavones and Argpyrimidines.

In order to assess the pharmacological efficiency of our proposed compounds we compared them with established inhibitors like PF-04494700 (Pfizer) and 4-fluorophenoxy analogs developed by Han et al. 2014 (specifically analogue 39 [5-(4-(4-(trifluoromethyl)phenoxy)phenyl)- N-(2-butoxy-4-(4(diethylamino)butyl)phenyl)-4 H-pyrazole-3carboximide] and analogue 40 [5-(4-(4-(fluorophenoxy) phenyl) - N-(2-butoxy-4-(4(diethylamino)butyl)phenyl)-4 $\mathrm{H}$-pyrazole-3carboximide]) [4]

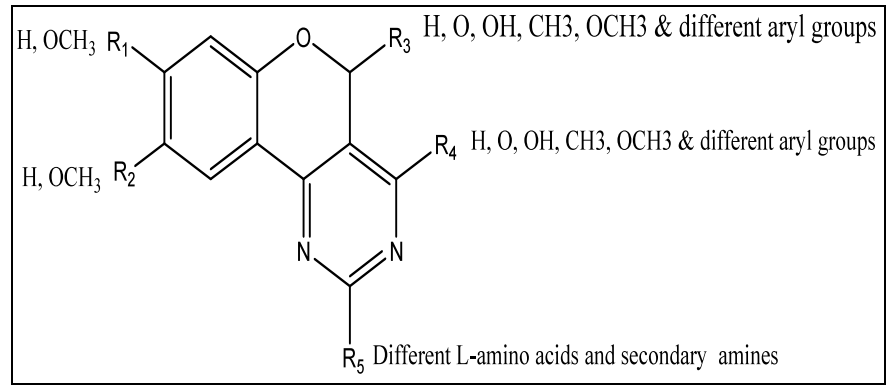

Figure 1: Basic scaffold of the designed compound along with different substitutions

Table 1: Pockets and descriptors for 3CJJ using DoGSiteScorer: Active Site Prediction and Analysis Server. Underlined cavity is the docking site.

\begin{tabular}{crrrrrr}
\hline $\begin{array}{c}\text { Cavity } \\
\text { number }\end{array}$ & $\begin{array}{l}\text { Volume } \\
{\left[\AA^{3}\right]}\end{array}$ & $\begin{array}{l}\text { Surface } \\
{\left[\AA^{2}\right]}\end{array}$ & $\begin{array}{l}\text { Lipo } \\
\text { surface } \\
{\left[\AA^{2}\right]}\end{array}$ & $\begin{array}{l}\text { Depth } \\
{[\AA]}\end{array}$ & $\begin{array}{l}\text { Simple } \\
\text { Score }\end{array}$ \\
\hline P0 & 452.8 & 769.3 & 541.3 & 12.5 & 0.30 \\
P1 & 340.1 & 583.6 & 369.6 & 13.1 & 0.20 \\
P2 & 245.5 & 472.6 & 294.3 & 16.8 & 0.09 \\
P3 & 186.2 & 453.4 & 262.3 & 9.9 & 0.04 \\
P4 & 175.2 & 439.4 & 334.5 & 10.0 & 0.10 \\
P5 & 159.3 & 381.9 & 230.4 & 7.7 & 0.03 \\
\hline
\end{tabular}

\section{Ligand and protein preparation:}

The structures of all the compounds were generated by Chemdraw suite [8]. The series of structures was further optimized and energy minimized using OPLS 2005 force field [9] through Ligprep module of Schrodinger Suite 2013 [10]. The ionization of the structures were retained at the original state and were further desalted. The structures, thus optimized were saved in .sdf format for docking procedures.

The crystal structure of RAGE was retrieved from Protein Data Bank (PDB) with accession number 3CJJ [11]. The structure was downloaded in .pdb format and was further prepared using the PrepWiz module of Schrodinger suite. During the preparation procedure, the protein was first pre-processed by assigning the bond orders and hydrogen, creating zero order bonds to metals and adding disulphide bonds. The missing side chains and loops were filled using Prime Module of Schrodinger. Further, all the water molecules were deleted beyond $5 \mathrm{~A}^{\circ}$ from hetero groups. Once the protein structure was pre-processed, $\mathrm{H}$ bonds were assigned which was followed by energy minimization by OPLS 2005 force field [9]. The final structure obtained was saved in.pdb format for further studies.

\section{Detection of active site:}

Extensive literature mining was done in order to deduce the active site in the protein (12-15). Further, the volumetric and surface area descriptors of the active site (Table 1) were calculated using Gaussian filter based DOG site finder [16]. The detected cavity in the RAGE receptor is shown in Figure 2.

\section{Molecular docking of compounds:}

Molegro Virtual Docker 2010.4.0, a Molecular docking program provides a flexible platform for docking and predicting how the molecules interact with protein receptor. The structure, based virtual screening of the compounds was based on rerank score, a mathematical representation for ligand-protein affinity which is based on MolDock scoring function (MolDock Score) derived from the Piecewise Linear Potential (PLP) scoring functions [17]. Further, the total energy was minimized using Nelder Mead Simplex Minimization (using non-grid force field and $\mathrm{H}$ bond directionality) [18]. Based on the internal electrostatic, hydrogen bond interactions and sp2-sp2 torsions binding affinity and receptor interactions with the compound were evaluated. Best compound with highest binding affinity against RAGE protein was selected as a function of rerank score.

\section{Bioactivity and ADMET profiling of compounds:}

Drug-likeness of the compounds was screened by Lipinski filters. Molinspiration webserver (@) Molinspiration Cheminformatics 2014) was used to predict the biological activity of ligands. $\mathrm{LC}_{50}$ was predicted using T.E.S.T. Version 4.1 (2012, U.S. Environmental Protection Agency) software. The complete ADMET properties were calculated using ADMETSAR [19]. LAZAR server was used to predict the mutagenic and carcinogenic potential of the compounds [20].

\section{Softwares, Suites and Webservers used:}

MarvinSketch 5.6.0.2, (1998-2011, Copyright (C ChemAxon Ltd) was used to design the compounds followed by optimization using LigPrep module of Schrodinger suite 2013. Protein preparation wizard of Schrodinger suite 2013 (Schrodinger. LLC, 2009, New York, NY) was used to prepare the protein. Molegro Virtual Docker 2010.4.0.0 was used to dock the compounds. Accelrys Discovery Studio® Visualizer 3.5.0.12158 (Copyright $($ 2005-12, Accelrys Software Inc.) was used for molecular visualizations. QikProp module of Schrödinger suite 2013 was applied to calculate various solubility parameters. LAZAR server was used to predict the mutagenic and carcinogenic potential of the compounds. Molinspiration web server (C) MolinspirationCheminformatics 2014) and ADMETSAR (Laboratory of Molecular Modeling and Design. Copyright @ 2012, East China University of Science and Technology, Shanghai Key Laboratory for New Drug Design) were used to predict bioactivity and ADMET profiles of the compounds. 
Table 2: Top four compounds demonstrating highest affinity (rerank score) against RAGE, of which compound 62 has the highest affinity for RAGE as predicted by molecular docking.

\begin{tabular}{clcccccc}
\hline & Ligand & $\begin{array}{c}\text { MolDock } \\
\text { Score }\end{array}$ & $\begin{array}{c}\text { Rerank } \\
\text { Score }\end{array}$ & Interaction & Internal & Torsions & HBond \\
\hline Designed compounds & 62 & -131.6 & -106.0 & -155.6 & 24.0 & 7 & -5.7 \\
& 326 & -118.1 & -89.0 & -131.4 & 13.3 & 11 & -9.9 \\
& 291 & -119.5 & -84.5 & -137.3 & 17.9 & 10 & -8.9 \\
\multirow{5}{*}{ Known } & 171 & -105.6 & -83.0 & -119.8 & 14.0 & 7 & -6.3 \\
\cline { 2 - 8 } Inhibitors & Pfizer (PF- & -118.7 & -81.5 & -125.6 & 7.0 & 4 & -12.0 \\
& 04494700) & & & & & & -1.7 \\
& Analogue 39 & -161.2 & -86.6 & -170.8 & 9.6 & 16 & -1.4 \\
\hline
\end{tabular}

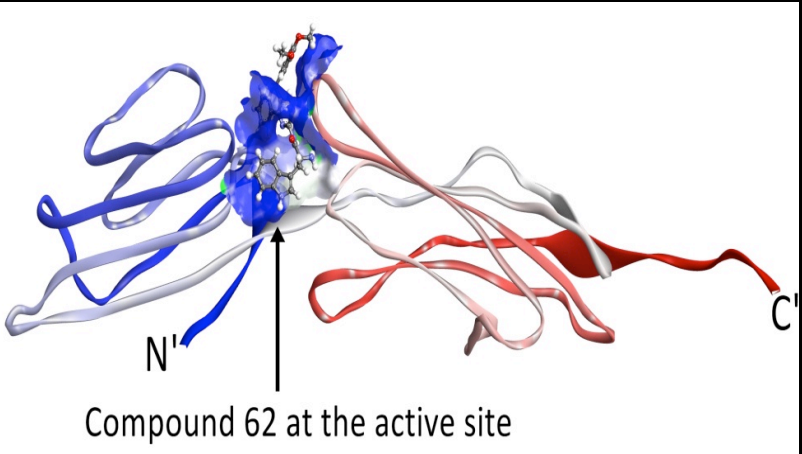

Figure 2: Compound 62 deeply embedded in the active site of RAGE receptor. The secondary structure is shown in blue to red spectrum represents ' $\mathrm{N}$ ' to ' $\mathrm{C}$ ' terminal of the polypeptide. The ligand receptor docking performed by Molegro Virtual Docker 2010.4.0.0. Molecular visualizations of the ligand receptor interaction were generated using Accelrys Discovery Studio® Visualizer 3.5.0.12158.

\section{Results \& Discussion:}

Top four compounds with best affinity along with established inhibitors Pfizer (PF-04494700) (Figure 3A), 4-fluorophenoxy analogs 39 (Figure 3B) and 40 (Figure 3C) against RAGE is shown in Table 2. Evident from the re-rank scores compound 62 (Figure 3D) shows highest binding affinity in comparison to all the designed compounds towards RAGE. Compound 62 showed almost 1.3 folds higher affinity than Pfizer (PF04494700) and almost 1.20 and 1.24 folds better affinity than4fluorophenoxy analogs 39 and 40 respectively. From the docking scores, therefore, it can be well assumed that compound 62 can form a high affinity candidate against RAGE receptor surpassing the binding efficiency of established inhibitors discovered hitherto.

In the further perusal, the pursuit was to reveal the rationale behind superior binding profile of compound 62 which can be deduced from the energy contributing descriptors of receptorligand interactions (as shown in Table 3). Apparent from the docking profile of interaction energy values the descriptors; external ligand interactions contribute 4.9 folds higher stability than internal ligand interactions. Further external ligand interactions were stabilized mostly by steric energy guided by piecewise linear potentials. While in internal ligand interactions, it's the torsional strain contributes to the stability of the ligand receptor interactions.

Table 3: Ligand- Receptor Interaction Energy overview of 62against RAGE. The external ligand interactions, especially stark energies (optimized piecewise linear potentials) contribute to stability of drug-receptor interactions.

\begin{tabular}{ll}
\hline Energy Overview: Descriptors & Kcal/mol \\
\hline Total Energy & -106.0 \\
External Ligand interactions & -133.0 \\
Protein - Ligand interactions & -133.0 \\
Steric (by PLP) & -102.8 \\
Steric (by LJ12-6) & -25.6 \\
Hydrogen bonds & -4.6 \\
Hydrogen bonds (no directionality) & 0 \\
Electrostatic (short range) & 0 \\
Electrostatic (long range) & 0 \\
Internal Ligand interactions & -27.0 \\
Torsional strain & 7.4 \\
Torsional strain (sp2-sp2) & 0 \\
Hydrogen bonds & 0 \\
Steric (by PLP) & 18.9 \\
Steric (by LJ12-6) & 117.2 \\
Electrostatic & 0 \\
\hline
\end{tabular}

In the next step, best-docked compounds 62 and 326 were tested for their ADMET properties. As shown in Table 4, both the compounds demonstrated to be safe showing noncarcinogenic and non-mutagenic property in different cell lines. In addition the $\mathrm{LC}_{50}$ values of both the best docked proposed compounds were appreciably less than all the established compounds viz. Pfizer (PF-04494700) and 4fluorophenoxy analogs 39 and 40. As elaborated in Table 5, the compounds proposed, in addition to non-toxic property, are also endowed with excellent absorption, distribution, metabolic and excretion profiles.

Poor oral absorption and lower solubility have always been a concern in the drug development process. In the present study, we tested; the absorption and solubility parameters of the 62 and 326 considering aqueous solubility and important partition co-efficients some of them being hexadecane/gas, octanol/gas and partition co-efficients (Table 6). Interestingly, both the compounds fall in the allowed range of solubility as predicted for $95 \%$ of all the FDA approved drugs. 
Table 4: In silico toxicity testing of compound in different cell lines for carcinogenic and mutagenenic property using LAZAR online server. All compounds screened in the study was found to be non carcinogenic (denoted as NC) and Non-Mutagenic (dented as NM). Compound 62 proposed in the study show least LC 50 value implying far better non -toxicity profile than all the compounds analyzed in the study.

\begin{tabular}{lllllll}
\hline & $\begin{array}{l}\text { DSSTox } \\
\text { Carcinogenic } \\
\text { Potency DBS } \\
\text { Mutagenicity }\end{array}$ & $\begin{array}{l}\text { DSSTox } \\
\text { Carcinogenic } \\
\text { Potency DBS } \\
\text { Rat }\end{array}$ & $\begin{array}{l}\text { Kazius-Bursi } \\
\text { Salmonella } \\
\text { mutagenicity }\end{array}$ & $\begin{array}{l}\text { EPA v4b Fathead } \\
\text { Minnow Acute } \\
\text { Toxicity } \\
\text { LC50_mmol }\end{array}$ & $\begin{array}{l}\text { DSSTox } \\
\text { Carcinogenic } \\
\text { Potency DBS } \\
\text { Hamster }\end{array}$ & $\begin{array}{l}\text { DSSTox } \\
\text { Carcinogenic } \\
\text { Potency DBS } \\
\text { Mouse }\end{array}$ \\
\cline { 2 - 7 } & $\mathrm{NM}$ & $\mathrm{NC}$ & $\mathrm{NM}$ & 0.002 & $\mathrm{NC}$ & $\mathrm{NC}$ \\
326 & $\mathrm{NM}$ & $\mathrm{NC}$ & $\mathrm{NM}$ & 0.007 & $\mathrm{NC}$ & $\mathrm{NC}$ \\
$\begin{array}{l}\text { Pfizer (PF- } \\
\text { 04494700) }\end{array}$ & $\mathrm{NM}$ & $\mathrm{NC}$ & $\mathrm{NM}$ & 0.008 & $\mathrm{NC}$ & $\mathrm{NC}$ \\
Analogue39 & $\mathrm{NM}$ & $\mathrm{NC}$ & $\mathrm{NM}$ & 0.166 & $\mathrm{NC}$ & $\mathrm{NC}$ \\
Analogue40 & $\mathrm{NM}$ & $\mathrm{NC}$ & $\mathrm{NM}$ & 0.005 & $\mathrm{NC}$ & $\mathrm{NC}$ \\
\hline
\end{tabular}

Table 5: ADMET prediction of virtually screened compounds by ADMETSAR server. Compound 62 shows appreciable ADMET properties than any compound analyzed in the study.

\begin{tabular}{|c|c|c|c|c|c|c|c|c|c|c|}
\hline & 62 & & 326 & & $\begin{array}{l}\text { Pfizer (PF- } \\
04494700\end{array}$ & & Analogue39 & & Analogue40 & \\
\hline & Result & $\begin{array}{l}\text { Probab } \\
\text { ility }\end{array}$ & Result & $\begin{array}{l}\text { Prob } \\
\text { abilit } \\
\text { y }\end{array}$ & Result & $\begin{array}{l}\text { Proba } \\
\text { bility }\end{array}$ & Result & $\begin{array}{l}\text { Proba } \\
\text { bility }\end{array}$ & Result & $\begin{array}{l}\text { Probabili } \\
\text { ty }\end{array}$ \\
\hline \multicolumn{11}{|l|}{ Absorption } \\
\hline Blood-Brain Barrier & BBB- & 0.7 & BBB- & 0.9 & $\mathrm{BBB}+$ & 1.0 & $\mathrm{BBB}+$ & 0.9 & BBB+ & 0.9 \\
\hline $\begin{array}{l}\text { Human Intestinal } \\
\text { Absorption }\end{array}$ & HIA+ & 1.0 & $\mathrm{HIA}+$ & 0.9 & HIA+ & 1.0 & HIA+ & 1 & HIA+ & 1 \\
\hline Caco-2 Permeability & Caco2- & 0.6 & Caco2- & 0.7 & Caco2- & 0.6 & Caco2- & 0.5 & Caco2+ & 0.5 \\
\hline $\begin{array}{l}\text { P-glycoprotein } \\
\text { Substrate }\end{array}$ & Substrate & 0.6 & Substrate & 0.7 & $\begin{array}{l}\text { Non- } \\
\text { substrate }\end{array}$ & 0.5 & Substrate & 0.8 & Substrate & 0.8 \\
\hline $\begin{array}{l}\text { P-glycoprotein } \\
\text { Inhibitor }\end{array}$ & $\begin{array}{l}\text { Non- } \\
\text { inhibitor }\end{array}$ & 0.6 & $\begin{array}{l}\text { Non- } \\
\text { inhibitor }\end{array}$ & 0.9 & $\begin{array}{l}\text { Non- } \\
\text { inhibitor }\end{array}$ & 1.0 & Inhibitor & 0.9 & Non-inhibitor & 0.9 \\
\hline $\begin{array}{l}\text { Renal Organic Cation } \\
\text { Transporter }\end{array}$ & $\begin{array}{l}\text { Non- } \\
\text { inhibitor }\end{array}$ & 0.9 & $\begin{array}{l}\text { Non- } \\
\text { inhibitor }\end{array}$ & 0.9 & $\begin{array}{l}\text { Non- } \\
\text { inhibitor }\end{array}$ & 0.8 & $\begin{array}{l}\text { Non- } \\
\text { inhibitor }\end{array}$ & 0.6 & Non-inhibitor & 0.6 \\
\hline \multicolumn{11}{|c|}{ Distribution \& Metabolism } \\
\hline CYP450 2C9 Substrate & $\begin{array}{l}\text { Non- } \\
\text { substrate }\end{array}$ & 0.9 & $\begin{array}{l}\text { Non- } \\
\text { substrate }\end{array}$ & 0.8 & $\begin{array}{l}\text { Non- } \\
\text { substrate }\end{array}$ & 0.7 & $\begin{array}{l}\text { Non- } \\
\text { substrate }\end{array}$ & 0.8 & Non-substrate & 0.9 \\
\hline CYP450 2D6 Substrate & $\begin{array}{l}\text { Non- } \\
\text { substrate }\end{array}$ & 0.8 & $\begin{array}{l}\text { Non- } \\
\text { substrate }\end{array}$ & 0.8 & $\begin{array}{l}\text { Non- } \\
\text { substrate }\end{array}$ & 0.8 & $\begin{array}{l}\text { Non- } \\
\text { substrate }\end{array}$ & 0.8 & Non-substrate & 0.8 \\
\hline CYP450 3A4 Substrate & Substrate & 0.7 & Substrate & 0.5 & Substrate & 0.6 & Substrate & 0.8 & Substrate & 0.8 \\
\hline CYP450 2C9 Inhibitor & $\begin{array}{l}\text { Non- } \\
\text { inhibitor }\end{array}$ & 0.7 & $\begin{array}{l}\text { Non- } \\
\text { inhibitor }\end{array}$ & 0.6 & $\begin{array}{l}\text { Non- } \\
\text { inhibitor }\end{array}$ & 0.7 & $\begin{array}{l}\text { Non- } \\
\text { inhibitor }\end{array}$ & 0.6 & Non-inhibitor & 0.6 \\
\hline CYP450 2D6 Inhibitor & $\begin{array}{l}\text { Non- } \\
\text { inhibitor }\end{array}$ & 0.9 & $\begin{array}{l}\text { Non- } \\
\text { inhibitor }\end{array}$ & 0.8 & $\begin{array}{l}\text { Non- } \\
\text { inhibitor }\end{array}$ & 0.7 & $\begin{array}{l}\text { Non- } \\
\text { inhibitor }\end{array}$ & 0.7 & Non-inhibitor & 0.7 \\
\hline CYP450 2C19 Inhibitor & $\begin{array}{l}\text { Non- } \\
\text { inhibitor }\end{array}$ & 0.6 & $\begin{array}{l}\text { Non- } \\
\text { inhibitor }\end{array}$ & 0.6 & $\begin{array}{l}\text { Non- } \\
\text { inhibitor }\end{array}$ & 0.7 & Inhibitor & 0.5 & Non-inhibitor & 0.5 \\
\hline CYP450 3A4 Inhibitor & Inhibitor & 0.7 & $\begin{array}{l}\text { Non- } \\
\text { inhibitor }\end{array}$ & 0.8 & $\begin{array}{l}\text { Non- } \\
\text { inhibitor }\end{array}$ & 0.6 & Inhibitor & 0.8 & Inhibitor & 0.6 \\
\hline \multicolumn{11}{|l|}{ Excretion } \\
\hline $\begin{array}{l}\text { Human Ether-a-go-go- } \\
\text { Related Gene } \\
\text { Inhibition }\end{array}$ & $\begin{array}{l}\text { Weak } \\
\text { inhibitor }\end{array}$ & 1.0 & $\begin{array}{l}\text { Weak } \\
\text { inhibitor }\end{array}$ & 0.9 & $\begin{array}{l}\text { Weak } \\
\text { inhibitor }\end{array}$ & 0.9 & $\begin{array}{l}\text { Weak } \\
\text { inhibitor }\end{array}$ & 0.9 & $\begin{array}{l}\text { Weak } \\
\text { inhibitor }\end{array}$ & 0.9 \\
\hline
\end{tabular}


A<smiles></smiles>

B

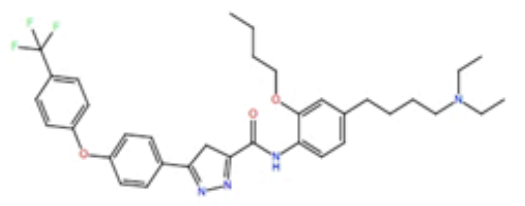

C<smiles>CCCCC1CC(CCCCC(CC)CC)CCC1CC1CCC(C2CCC(CC3CCC(C)CC3)CC2)C1C</smiles>

D

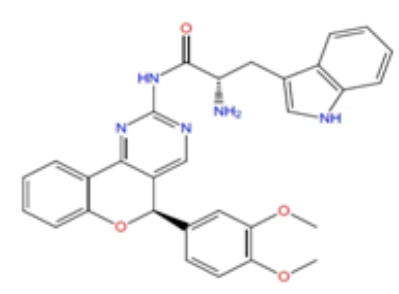

E

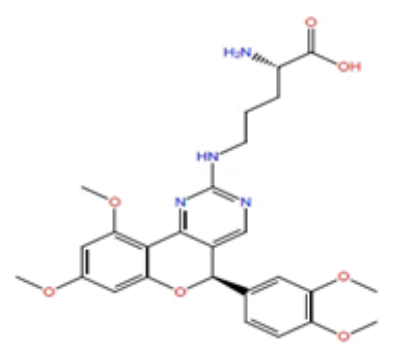

Figure 3: Chemical structures of (A) Pfizer (PF-04494700) (B) Analogue 39(C) Analogue 40(D) Compound 62- [(2S)-2-amino-3(1H-indol-3yl)-N-(5-(3,4-dimethoxyphenyl)-5H-chromeno[4,3-d] pyrimidin-2-yl)propanamide] and (E) compound 326.
A

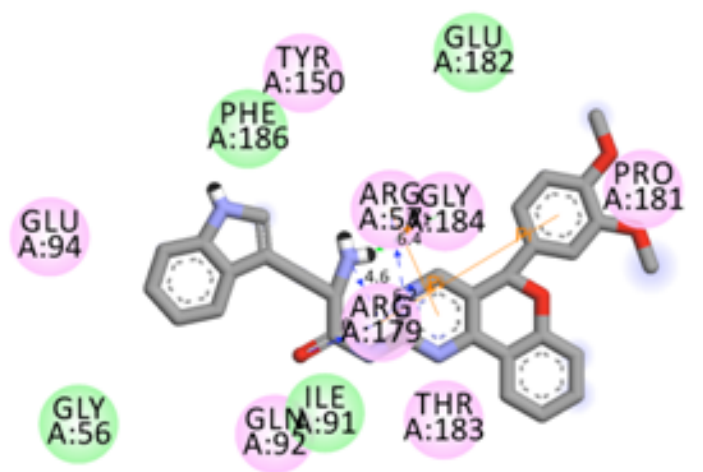

B

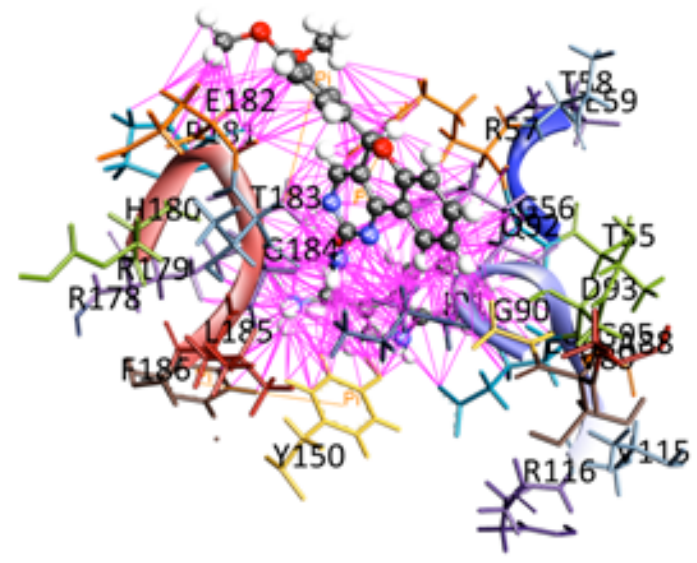

Figure 4: (A) Interactions of 62 in the active site of RAGE receptor. Residues circled in green participate in van der Waals interaction with the ligand while residues in pink forms electrostatic interactions. Hydrogen bonds are shown as green and blue arrows between ligand and residues ' $R$ ' 54; ' $R$ ' 179 and ' $G$ ' 184. (B) Ligand Binding pattern of 62 in the active site. The pink lines represent various interactions like electrostatic, van der Waals, stearic, hydrogen bonding and hydrophobic interactions that enable energetically favorable binding of the ligand in the receptor.

Owing to optimal affinity, high inhibitory activity and nontoxicity of 62, it was further analyzed for pharmacophoric mappings. Comprehensively shown in Figure 4, the compound demonstrates van der Waals interactions with ' $F$ ' 186 , ' $E$ ' 182, ' $\mathrm{I}$ ' 91, 'G' 56, 'G' 90 and electrostatic interactions with ' $E$ ' 94, ' $Y$ ' 150, ' $\mathrm{R}$ ' 54 and 179, ' $\mathrm{G}$ ' 184, ' $\mathrm{P}$ ' 181, 'T' 183 and 'Q' 92. The compound 
is a hydrogen bond donor to Arginine residues ' $R$ ' 54 and 179 while hydrogen acceptor from ' $G$ ' 184 . In addition pi-pi interactions between ligand's aromatic centers to ' $R$ ' 54 and ' $R$ ' 179. From the interaction map it can be deduced that, the electrostatic interaction plays stupendous role in stabilizing the 62 in the active site of the RAGE than any other. In addition, it can be also observed the electrostatic reactive residues like ' $R$ ' 54 and ' $R$ ' 179 are involved in major interactions involving hydrogen bonds and pi-pi interactions. Therefore, from the ligand-binding pattern we can assume ' $R$ ' 54 and ' $R$ ' 179 are the confounding residues in the interaction of the ligand. We speculate that in any case ligands fails to interact to these residues or otherwise, these residues are substituted in the course of peptide mutations, the ligand-receptor interactions may be drastically impede which may otherwise lead to ineffective treatment and patients may likely develop refractoriness against RAGE inhibitors. Electrostatic and hydrophobic interaction in 62 is shown in Figure 5A and 5B respectively. Considering, high affinity against RAGE, along with appreciable ADMET and solubility properties, interaction profiles and pharmacophoric features, we anticipate compound 62 may form a potential candidate for RAGE inhibition in clinical treatment of diabetic retinopathy.

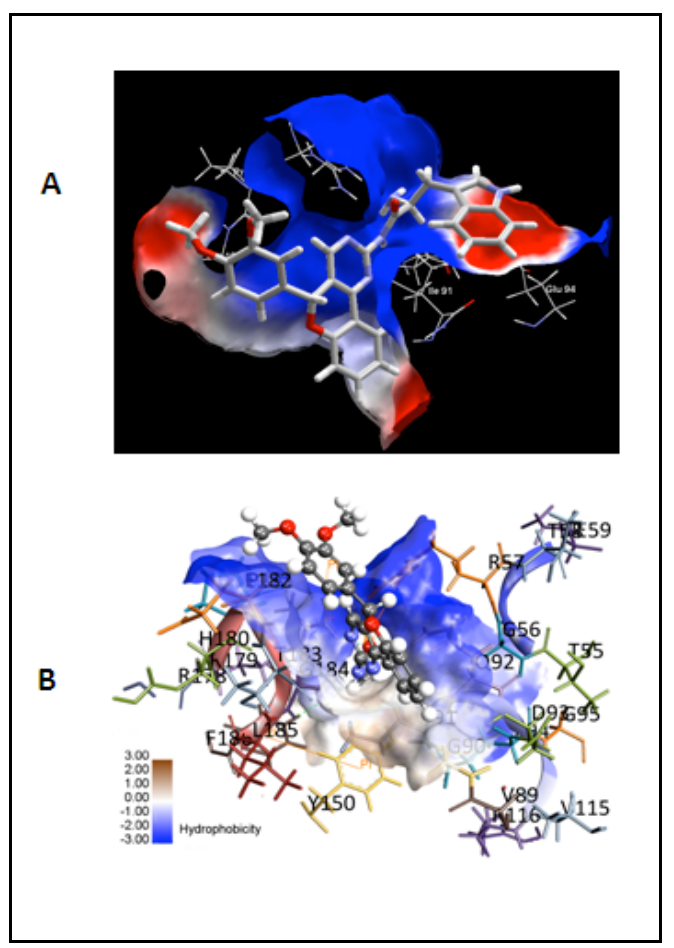

Figure 5: (A) Compound 62 deeply embedded in the allosteric site surrounded by highly electronegative residues. (B) The site harboring compound 62 is shown with hydrophobic intensities. The hydrophobic intensities of the binding site ranges from -3.00 (least hydrophobic area - blue shade) to 3.00 (highly hydrophobic area - brown shade).
Table 6: Predicted solubility properties of compounds. The compound 62 demonstrates optimal soluble properties in the range of $95 \%$ of known drugs.

\begin{tabular}{|c|c|c|c|}
\hline Parameters & 62 & 326 & $\begin{array}{l}\text { Range for } 95 \% \text { of } \\
\text { drugs }\end{array}$ \\
\hline $\begin{array}{l}\text { QP Polarizability } \\
\left(\text { Angstroms }{ }^{\wedge}\right)\end{array}$ & $57.6 \mathrm{M}$ & $47.9 \mathrm{M}$ & $(13.0 / 70.0)$ \\
\hline $\begin{array}{l}\text { QP log P for } \\
\text { hexadecane/gas }\end{array}$ & $17.7 \mathrm{M}$ & $15.5 \mathrm{M}$ & $(4.0 / 18.0)$ \\
\hline QP $\log$ P for octanol/gas & $30.0 \mathrm{M}$ & $27.0 \mathrm{M}$ & $(8.0 / 35.0)$ \\
\hline QP $\log P$ for water/gas & $18.1 \mathrm{M}$ & $16.6 \mathrm{M}$ & $(4.0 / 45.0)$ \\
\hline QP $\log$ P for octanol/water & 4.6 & 1.3 & $(-2.0 / 6.5)$ \\
\hline $\begin{array}{l}\text { QP } \log S \text { for aqueous } \\
\text { solubility }\end{array}$ & -6.5 & -4.7 & $(-6.5 / 0.5)$ \\
\hline $\begin{array}{l}\text { QP } \log S \text { - conformation } \\
\text { independent }\end{array}$ & -7.0 & -7.0 & $(-6.5 / 0.5)$ \\
\hline $\begin{array}{l}\text { QP log K hsa Serum } \\
\text { Protein Binding }\end{array}$ & 0.8 & 0.1 & $(-1.5 / 1.5)$ \\
\hline QP $\log$ BB for brain/blood & -1.0 & -1.7 & $(-3.0 / 1.2)$ \\
\hline No. of Primary Metabolites & 8 & 9 & $(1.0 / 8.0)$ \\
\hline Predicted CNS Activity & -- & -- & $(--$ to ++$)$ \\
\hline $\begin{array}{l}\text { HERG K+ Channel } \\
\text { Blockage: log } \mathrm{IC}_{50}\end{array}$ & -8.6 & -4.5 & (concern below -5 ) \\
\hline $\begin{array}{l}\text { Apparent Caco-2 } \\
\text { Permeability (nm/sec) }\end{array}$ & 121 & 10 & ( $<25$ poor, $>500$ great $)$ \\
\hline $\begin{array}{l}\text { Apparent MDCK } \\
\text { Permeability (nm/sec) }\end{array}$ & $56 \mathrm{M}$ & $4 \mathrm{M}$ & ( $<25$ poor, $>500$ great) \\
\hline $\begin{array}{l}\text { QP } \log K p \text { for skin } \\
\text { permeability }\end{array}$ & -3.7 & -5.4 & $(\mathrm{Kp}$ in $\mathrm{cm} / \mathrm{hr})$ \\
\hline
\end{tabular}

\section{Conclusion:}

The narrow therapeutic range of established RAGE inhibitors necessitates an urgent need in the treatment of DR. We report the identification of compound 62 with high affinity and solubility properties along with less toxicity than established RAGE inhibitors.

\section{References:}

[1] Guariguata L Diabetes Res Clin Pract. 2013 100(2): 280 [PMID: 23522917]

[2] Yau JW et al. Diabetes care DC: 2012 35(3): 556 [PMID: 22301125]

[3] Han Y et al. J Med Chem 2012 55: 9120

[4] Han Y et al. J Med Chem 2014 79: 128

[5] Li X et al. J Agri \& Food Chem 2014 62: 12152 [PMID: 25412188]

[6] Lv L et al. Chem Res Tox 2011 24: 579 [PMID: 21344933]

[7] Shao X et al. J Agri \& Food Chem 2014 62: 3202 [PMID: 24689984]

[8] Mills et al. J Am Chem Soc. 2006 128: 4113649

[9] Jorgensen WL \& Tirado-Rives J, Proc Natl Acad Sci USA. 2005 102: 6665 [PMID: 15870211]

[10] Ligprep V. 2.3, Schrodinger. LLC, New York, NY. 2009 
[11] Koch et al. Structure. 2010 18: 10 1342. [PMID: 20947022]

[12] Fatchiyah et al. Acta Informatica Medica. 2015 23: 2 90. [PMID: 26005274]

[13] Alexiou P et al. Curr Med Chem. 2010 17: 21 2232. Review. [PMID: 20459381]

[14] Matsumoto S et al. Biochemistry. 2008 25: 4712299 [PMID: 19032093]

[15] Ishihara K et al. FEBS Lett. 2003 28: 550 107. [PMID: 12935895]
[16] Volkamer et al. J. Chem. Inf. Model. 2010 50: 11, 2041. [PMID: 20945875]

[17] Thomsen \& Christensen. J Med Chem 2006 49: 113315.

[18] Nelder JA \& Mead R, Comput J. 1965 7: 308

[19] Cheng F et al. J ChemInf Model. 2012 52: 3099 [PMID: 23092397]

[20] Maunz A et al. Front Pharmacol 2013. 4: 38 [PMID: 23761761]

Edited by P Kangueane

Citation: Alaparthi et al. Bioinformation 12(3): 124-130 (2016)

License statement: This is an Open Access article which permits unrestricted use, distribution, and reproduction in any medium provided the original work is properly credited. This is distributed under the terms of the Creative Commons Attribution License

\section{BIOMEDICAL}

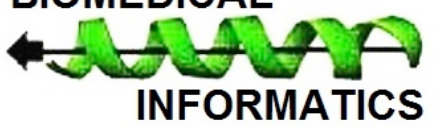

